\title{
Building a supportive teaching culture to increase teaching effectiveness
}

\author{
Le Bich Thuy
}

\begin{abstract}
This paper investigates the existence of a campus supportive teaching culture in a Vietnamese public university that can facilitate good teaching, basing on three research questions aiming to find out: (1) the availability of supportive teaching activities at campus and (2) the effectiveness of such practices from lecturers' perspectives and (3) the demand for similar or more activities for teaching excellence. The study was conducted in the form of a survey, with data gathered via an online questionnaire. From data analysis and findings, a number of methods are suggested to enhance or establish a supportive teaching culture in other Vietnamese universities accordingly.
\end{abstract}

Key words-Campus culture, teaching excellence, teaching effectiveness, teaching culture, feedback...

\section{INTRODUCTION}

$\mathrm{R}$ ECENTLY there has been a gradual shift toward research-oriented universities and the perception is that at an increasing number of universities, teaching effectiveness is seemingly less appreciated than research productivity. Efforts have been made, as a result, with the purpose of increasing the number of publications, especially international ones while teaching quality tends to be regarded as something obviously having been acquired by lecturers. In many Vietnamese higher institutions, a common current method to assess the lecturers' teaching quality mainly bases on student's end-of-course feedbacks (in some rare cases on peers' evaluation) and less attention has been paid on the encouragement of good teaching, especially in research-oriented universities. However, it is apparent that once lecturers' effort and teaching quality are assessed merely basing on the number of courses they teach annually or on

Received: 22-6-2018, Accept: 24-8-2018, Published: 2910-2018.

Author Le Bich Thuy, University of Economics and Law, VNUHCM, Viet Nam (e-mail: thuylb@uel.edu.vn). students' objective view, it is unlikely to have appropriate and reliable outcomes. In addition, while a lot of factors such as course nature (mandatory or non-mandatory), teaching hours and teaching practice can influence responses on such evaluations, rankings are rarely directly comparable among courses or instructors.

"There are many kinds of good teaching, in many kinds of teaching situations, at many different levels. Attempts to reduce it to a formula are doomed to failure. There will always be teachers who will break all our rules and yet be profoundly successful. In other words, it is the good teacher, not teaching on the abstract that counts" (Peng, 2014)

In fact, it is undeniable that school cannot succeed unless it focuses on creating the conditions under which teachers can teach and teach well. In addition, lecturers' quality of teaching can both positively and negatively influenced by institutional cultures and whether school culture values teaching or not may either demotivate or motivate faculty to excellence in teaching. The aim of this research paper is to find out the availability of supportive activities that facilitate good teaching at a Vietnamese public university and the effectiveness of such practices from lecturers' perspectives. The results entail suggestions for the establishment or enhancement of a supportive teaching culture in other Vietnamese universities accordingly.

\section{LITERATURE REVIEW}

Different researchers define the term "teaching effectiveness" in different ways. In her study, when asking those concerned ( teachers, students and administrators) what the term means to them, Maryellen Weimer [22] get result that showed a list of the three most important abilities including: cultivate thinking skills, stimulate interest in the subject, and motivate students to learn. 
Meanwhile, in another study, researchers compared the words and phrases students used to describe effective and ineffective teachers and the top three words used to characterize teachers with the highest ratings were: interesting, approachable, and clarity [22]. The definition extracted from descriptions of teachers nominated for teaching awards used these words: approachable, presents material well, makes subject interesting, helpful, and knowledgeable.

Research has suggested that a collaborative teaching culture may positively impact school achievement $[15,7,9]$ and that "student learning will improve when lecturers commit themselves to talking collaboratively about teaching and learning and then take action that will improve student learning and achievement" [17]. When the school has a collaboration culture that supports teaching and learning, not only will students achieve but the school will also benefit in terms of an increase in faculty members' confidence, innovation expansion as well as methods and materials availability to each teacher and ability to test new ideas and provide greater support for new teachers entering the school [15, 2] (Rebecca DuFour, 2004). (Bland, 2007) also stated that "student believe in their ability to learn because everyone is learning. Professional learning communities are a powerful resource for creating the kind of school that every student and teacher appreciates and values. Therefore, many of the professional development activities for teachers center around improving student achievement through improved teacher practices". In fact, schools with higher levels of teacher collaboration are associated with stronger student performance [23]. Additionally, teachers were more likely to produce student achievement gains if they taught in schools where they had strong ties to colleagues with whom they worked often on instructional issues regardless of their education, experience [8]. The development of a collaborative teaching culture has consequently been suggested as a means of advancing teacher communication and knowledge to improve teaching quality $[7,12]$ (Fullan)

Institutional culture refers to the norms and values that are embedded in the daily life of an organization. In higher educational institutions, key aspects of academic culture include the autonomy and academic freedom, integrity and collegiality. A culture characterized by collegiality (mutual respect, support and appreciation among academic staff) is an essential ingredient to fostering good work in the academy [6].

Building a supportive teaching culture constitutes a context that promotes the availability of informative feedback in various forms about an individual's teaching effectiveness, which in turn stimulates teachers' motivation for instructional excellence. In a supportive teaching culture, informative feedback is readily available from several sources- colleagues, chairs, students and teachers themselves- to address the needs of faculty for self- determination and excellence in teaching, to provide opportunities to learn and achieve, and to stimulate, inform and support efforts to improve instruction (and to sustain these improvements over time).

A number of prominent and salient characteristics of cultures that support teaching and its improvement includes:

High- level administrative commitment and support: It is significant that senior administrators commit an effort of maintaining excellence in teaching. When instructional activities are given high visibility by the senior administration, their importance is thereby illustrated [20].

Faculty involvement, shared values and a sense of ownership: The widespread involvement of faculty in every aspects of planning and implementing activities that encourage instructional excellence and improvement is necessary to increase the chances for shared values between administrators and faculty $[13,16,19]$.

Frequent interaction, collaboration and community among faculty: Institutional and department cultures that support teaching are characterized by opportunities for frequent interaction among faculty on teaching- related issues. The intrinsic rewards of teaching are the availability of opportunities to talk about teaching [21].

A faculty development program or campus teaching center: Campus cultures that value teaching are also characterized by extensive faculty development programs [4], often coordinated by the staff of a campus teaching centre. The resources and programs of teaching centers might include some or all of the following: individual consultations, department consultations, 
workshops, seminars, conferences, teaching assistant training programs, annual award programs, materials on teaching development and institutional participation in grants and research on teaching and faculty development.

Supportive and effective department chairs: Rice and Austin (1990) (Paulsen, 2002) described the essential role of the department chairs as follows: "Department chairs can convey to faculty members information about how teaching efforts are valued, how time is most profitably allocated, and on what basis rewards are determined... Without the support of department chairs, many incentives to encourage good teaching may be fruitless" (p.39) [13]

Chairs of department are important to maintaining high motivation and excellence teaching, as well as improving instruction. One way they help is by providing support- financial and otherwise- to ongoing formal and informal attempts to improve teaching and to reward existing instructional excellence. Moreover, they are invaluable in defining faculty development and instructional improvements as important departmental activities. Connecting evaluation of teaching to promotion decisions: a common and outstanding characteristic of teaching cultures is the use of colleagues and student evaluation of teaching and the connection of this evaluation to promotion decisions [10]. A range of strategies using colleagues to help improve teaching or to maintain motivation for instructional excellence include the renewed use of team teaching [13] and collegial coaching [3]. Faculty collaboration through team teaching benefits lecturers by developing or maintaining their teaching abilities, intellectually stimulating them, engaging them as self- directed learners and more closely connecting them to the university or college as a community. Research has shown persistently that feedback from student ratings is of value in improving teaching [18].

Accordingly, a number of programs have been suggested to create a supportive culture of teaching including: a teaching fellows program, a celebration of teaching dinner, a center for teaching development, an annual teaching assistant orientation or deans and chairs conference [11].

In a teaching fellows program, teaching fellows do not receive any direct compensation but are provided with release time from their teaching, usually $50 \%$ of their total teaching commitment for an academic year to participate in program activities. Fellows attend a biweekly "seminar on university teaching", work on a project for their home academic department (usually the development of a new course or the revision of an existing course), engage in an individual consultation process (e.g. Class visits, student feedback) and work with a senior faculty mentor.

The celebration of teaching dinner provides an occasion at which members of the university community across discipline, departments and ranks come together to publicly acknowledge and celebrate the important of teaching. It is not an award program but rather an event where faculty come to hear other faculty talk about their teaching. Teaching fellows may have presentations, dealing with either memorable experience they have during their teaching career.

A center for teaching development is necessary to be in charge of offering a range of resources and programs for enhancing teaching and learning. They include individual consultations, department consultations, workshops, seminars, conferences, teaching assistant training programs, annual award programs, materials on teaching development and institutional participation in grants and research on teaching and faculty development. The center also organizes teaching assistant orientation event in which experienced teaching assistants or lecturers share their perspective and advice on becoming a teaching assistant or a university lecturer.

\section{RESEARCH METHODOLOGY}

This research focuses on finding out the existence, effectiveness of and a demand for a supportive teaching culture in a chosen Vietnamese public university. The implications for building a culture that supports excellence in teaching and enhances the teaching quality are the objectives of the study. In order to successfully gain those aims, the following research questions were designed:

$1 /$ What are the impacts of school policies on the improvement of lecturers' teaching competence?

2/ What can be done to improve teaching competence of lecturers at campus? 
Data was collected through one questionnaire containing eight (8) open questions for respondents to express their opinions in the most comfortable way. They were used as the main source of data collection in this study for two reasons: First, the use of questionnaires allows investigators to collect a considerable amount of data within a relatively short time. Furthermore, with questionnaires, the respondents can avoid fear and embarrassment of direct contact with the researcher. Questionnaires are distributed to the emails of all fulltime lecturers (231 people) of the chosen university, including both senior and newly recruited ones. However, there were only 162 responses. The data was, then, analyzed.

\section{FINDINGS AND DISCUSSIONS}

Among more than two hundred fulltime lecturers including both senior and junior ones invited to the online questionnaire, 162 answers were collected.

Regarding the question of which competence (teaching or research) the university values more, most of respondents $(88.27 \%$, including all young lecturers) chose research competence. Clarifying their choices, faculty members gave the following reasons:

- School rewards lecturers with good research competence basing on the number of publications, especially international ones. There are a lot of criteria to evaluate research competence such as: publications, research projects, articles, etc ...while there is only one criterion to assess teaching competence (containing a lot of bias and risks) which is students' end-of-course feedbacks.

- Faculty members with excellence in publications and numerous research scores are highly recognized and appreciated by school administrators, especially by the Rector. Their names are mentioned and complimented in almost all school meetings.

- Competition among faculties also bases on research competence of faculty members, not teaching competence;

- There are a lot of supporting activities organized by both school and faculties to improve lecturers' research competence while such practice is limited in terms of teaching competence;
- If lecturers receive negative feedbacks from students (low scores), they face no problems. However, if they do not fulfill their research obligations, their faculties will be named in school meetings and their reputation will be negatively affected.

Concerning the second question asking whether faculty members spend more time to improve their teaching competence or research competence and why they allocate more time for such activities, surprisingly, more than half of answers were for teaching enhancement (60.49\%) and nearly half was for research. The lecturers spending more time to improve their teaching ability than research one claimed that the most important mission of a lecturer was to teach well and to inspire students to life long learning and that if one did not know how to teach well, he/she should not be a lecturer. Without good teaching methods and profound knowledge in the field from faculty members, it is easy for students to lose concerntration in studying and soon find no motivation for self-development. Moreover, facing the increasingly high demand from learners, lecturers need to be better prepared for each lessons in order to win respect from their students. Without good research results, faculty members may later have troubles with administrators but without good teaching skills, they surely have immediate problems with their students, like students' frequent absence, bored and sleepy faces in classes, etc. To respondents who reserved more time for research competence enhancement, teaching excellence is born, not made, so they argued that there is not much to do about that while research effectiveness can be acchieved with appropriate training and practices. Furthermore, they explained that the importance of each courses should be well realized and acknowledged by learners themselves. With good realisation and acknowledgement, students will be more aware of their own learning regardless of teacher's teaching methodology. In addition, they also reasoned that the improvement of their research competence was their priority in this period for the fact that in recent years, especially in the year of 2018, university strategic plans was to focus on research competence of faculty members, especially to increase international publications. The fact that all efforts of the school clearly and repeatedly conveyed by university leaders was to promote 
research activities consequently instructed lecturers to develop themselves towards research improvement rather than teaching. Among the abovementioned respondents, twenty five were young and newly recruited faculty members.

In relation to the questions of how school evaluated their teaching quality, all of respondents informed that student end- ofcourse rating was chosen by administrators as the major channel of evaluation (beside official peer evaluation for newly recruited faculty members and in some faculties peers observe classes to give comments). Nineteen faculty members $(11.72 \%)$ satisfied with such method and stated that students were quite competent to report on the extent to which a lecturer appears prepared for class sessions, communicates clearly as well as stimulates interest and demonstrates enthusiasm and respect for students. Meanwhile, one hundred and forty three lecturers (88.27\%) disagreed with this evaluation method for many reasons. Among some of the most common reason is the argument that it is quite easy to positively affect student feedbacks as long as lecturers are nice to them and do not impose heavy workload on them. Some lecturers argued that students were totally unable to judge the knowledge of the instructors or scholarly content and that when lecturers focused too much on the academic content and were serious about the requirements of class participation and attendance, there was a high tendency that students would provide negative feedback.

Specifically, some of their comments are as follows:

- Students are not competent enough to judge the knowledge of the instructor and which teaching method is good for them;

- Students' view points are so easy to be affected by too many factors: If lecturers are serious in teaching, they may get unsatisfactory feedbacks; Iif lecturers are easy going and do not focus too much on the academic knowledge (which is usually hard to understand)and tell jokes in class or let students play games, students will feel less stressful and give positive comments;

- With large classes, whichever techniques will be ineffective and it is very unlikely that learners feel satisfied with the course to give positive comments;

- Some obligatory courses are too academic and less appealing than the others (like soft skills classes or language classes). So it is unfair just to rely on students' satisfactions to evaluate lecturers' teaching quality;

- It is inappropriate to let students judge the teaching effectiveness. They are incapable of doing such thing. What they consider inappropriate or not good at present may turn out to be extremely useful for them when they work in reality.

At the same time, respondents also remarked that the current evaluation method using student ratings sometime threatened their face and some stated that they did not want to be assessed by their peers even when their colleagues had more experience and especially when their colleagues were younger than them. An undeniable fact is that in Asia, personal connections and networks are very important. These personal relationships affect all aspects of the work and processes within higher educational institutions. Some cultural norms that frame academic relationships in Asian higher education institutions are the importance of hierarchy, the predominant respect for age and especially the domination of "face" keeping (Bank, 2011). While opportunities for early-career faculty members to learn from their colleagues are important, the cultural norms in Asia mean that colleagues must typically defer to other faculty members in ways that faculty members tend to avoid making their colleagues loose faces by giving comments on their teaching unanonymously. In Vietnam, face keeping is especially of great importance and hence any potential face threatening acts should be seriously considered. In addition, there is no simple system for evaluating the quality of faculty teaching so it is necessary to ensure that the evaluation system adopted is credible and acceptable by faculty members by letting them be involved in determining their criteria for effective teaching.

Concerning teaching supportive activities available for lecturers at campus, it was reported by all respondents that before the year of 2017 , there had been very little or even no attention paid by the school to lecturers' professional development activities. From 2017, school began to organize training sessions for faculty members on teaching techniques, including how to design 
courses following CDIO (Conceive- DesignImplement-Operate) standards. However, the real purpose of such programs was to award faculty members with teaching certificates as an official statutory requirement from the Ministry of Education or to satisfy the requirements of CDIO project rather than to truly improve their teaching competence. As a result, a majority of lecturers participated without enthusiasm and in lack of positive motivation, leading to unnoticeable improvement in teaching effectiveness. Also at the end of academic year 2016-2017, school offered ten awards for "lecturers of the year", totally based on student feedbacks, which can be considered as one of teaching supportive activities.

At faculty level, one among 8 faculties applies collegial style to support lecturers for the enhancement of their teaching effectiveness. Peers teaching same courses or relevant courses are asked to work closely with each other to prepare materials for their lessons and share experience in teaching as well as prepare lesson plans. Respondents commented that as long as they were not judged by their colleagues, they thought the communication between peers to support each other in teaching very fruitful and useful. They learnt from their peers and felt more confident in teaching.

Being asked to suggest some supporting activities at campus with the purpose of improving teaching competence, respondents mentioned the necessity of having appropriate policies from school to encourage excellence in teaching, creating a community where faculty members can share experience, materials and assist each other, organizing sessions to continuously equip lecturers with new and effective teaching technique, providing assistance in preparing materials for classes and class management (especially large size classes). Furthermore, faculty members also stated a demand for a forum for senior lecturers and young faculty to frequently interact on teaching-related issues, consultations and supports on teaching techniques as well as the urgent need of a fair and reliable award program basing on reliable evaluation methods and especially the requirement of easing the burden of teaching duty and researching duty.

\section{IMPLICATIONS AND CONCLUSION}

When young faculty starts their lecturer positions, they are often expected to quickly master teaching techniques within one year after recruitment. However, new faculty have little training on or exposure to teaching and virtually no experience with the culture of teaching and learning communities. Apparently, senior colleagues could serve as sources of teaching support, advice, and feedback for new faculty, but those new faculty may be reluctant to get involved in such relationship for several reasons. One is the tradition of academic freedom, in which classrooms are viewed as private worlds where faculty members have the freedom to conduct their courses as they think appropriate. Less experienced faculty also may be reluctant to share their ideas and concerns about teaching and learning because they fear exposing their pedagogical naiveté. Even senior faculty members, after some years of lecturing, in spite of becoming more experienced, see the need of being provided with new teaching methods for the fact that learners are increasingly different from those of the old days as a result of technology revolution. It is also very useful for them to have a chance listening to younger ones who are energetic, enthusiastic and innovative to keep the latest technology and trend.

Moreover, because the focus of many institutions is productivity in independent research and the pressure to pursue research actively also makes it difficult for them to gain excellence in teaching, faculty members may view negatively the time they spend teaching. Without the provision of appropriate teaching supporting activities, it is likely that teaching competence of lecturers will sooner or later be negatively affected.

Findings of the research conducted at the chosen public university show that the existence of a campus culture supporting teaching excellence is still vague in such institution although the characteristics may include a reward system for teaching excellence (simply based on student endof-course evaluation) and some teacher development activities offered. However, the lack of more active and frequent colleague collaboration in teaching-related issues, the shortage of adequate school policies to encourage 
and recognize the improvement and efforts in teaching and of a complete systems to support and maintain teaching excellence does imply the necessity of the establishment of such culture in not only the university studied but also in other Vietnamese universities. Among three key aspects of academic culture (suggested by Gappa et all, 2007), it seems that autonomy and academic freedom are too respected while the collegiality requesting the mutual support and appreciation in teaching tends to be relatively neglected.

In order to build up a campus culture that support teaching and help a teaching community to flourish, it is advisable that the following strategies should be considered:

First, it is essential that institutions identify existing supports for teaching at campus. Obviously there are a number of faculty and administrators who have strong commitment to teaching but have not been identified and have no forum to express their support for teaching and meet colleagues with similar views. Engaging these individuals is a first step in building supportive teaching community.

Secondly, a campus teaching development center needs to be set up to help lecturers frequently improve their teaching skills. While faculty who need help in their teaching should be welcomed and supported, teaching centers also need to bring together the best teachers on campus for the purpose of improving teaching for all faculty and should use outstanding faculty to provide programming and new experiments to improve teaching. More than that, a community and collegiality around teaching should be created. Despite the autonomy offered by an academic career, it is significant that faculty can get support from each other. Lecturers and researchers in the field need to be brought together so that they can talk and share opinions about teaching. It can also help to create a sense of community that helps to break down the isolation felt by many university lecturers.

Additionally, building and enhancing a teaching culture at research-oriented universities cannot be effectively accomplished if these efforts are in conflict with the research culture of the institution. If the teaching development effort is perceived as being integrated with the research mission rather than in competition with it, it is more likely that such effort get more support from administrators. A period of release time to participate in the teaching development program can provide faculty with additional time to work on research also.

Finally, to successfully create a supportive teaching culture at campus, recognition and reward for excellence teaching should be provided with prudence, basing on reliable evaluation methods. All efforts to improve teaching should be taken noticed and give them as much publicity as possible. Such efforts include not only distinguished teaching awards but also opportunities for faculty and academic leaders to present their ideas and programs on teaching and their efforts are well recognized. Such recognition can be easily provided through the celebration of teaching dinners or the like, school newspaper publicity.

To sum up, to improve teaching quality at higher education institutions in Vietnam, building a campus supportive teaching culture is of great importance within the request of more efforts to investigate on effective strategies taking into account the cultural factors. The research offers implications for such purpose by suggesting four activities to enhance or establish a supportive teaching culture in Vietnamese universities in general. Limitations of the research may arise as a result of differences in governance between public and private universities and need further researches.

\section{REFERENCES}

[1] Bank, A. D. (2011). Improving Instructional Quality: Focus on Faculty Development.

[2] Bland, K. D. (2007). Relationship of Collaborative School Culture and School Achievement. Retrieved from https://digitalcommons.georgiasouthern.edu/cgi/viewcon tent.cgi?referer=https://www.google.com/\&httpsredir=1 \&article $=1786$ \&context $=$ etd.

[3] Dantonio, M. (1995). Collegial Coaching: Inquiry in the Teaching Self (Research for the practitioner series). Phi Delta Kappa Intl Inc .

[4] Finkelstein, L.-P. a. (1993). Organizational Impacts on Faculty Morale and Motivation to Teach. In P. S. Associates, How Administrators Can Improve Teaching: Moving from Talk to Action in Higher Education. San Francisco: Josey - Bass.

[5] Fullan, M. (n.d.). Professional learning communities. In E. R. DuFour R, On common ground: The power of professional learning communities (pp. 209-223). Bloomington.

[6] Gappa, J. M. (2007). Rethinking faculty work: Higher education's strategic imperative. San Francisco, CA,: US: Jossey-Bass. 
[7] Jessie, L. G. (2007). The Elements of a Professional Learning Community. Retrieved from https://www.naesp.org/sites/default/files/resources/2/Lea dership_Compass/2007/LC2007v5n2a4.pdf.

[8] Leana, C. R. (2011). The Missing Link in School Reform. Retrieved

from https://ssir.org/articles/entry/the_missing_link_in_school reform.

[9] McTighe, J. (2007). Making the Most of Professional Learning Communities. Retrieved from file://C:/Users/thuylb/Downloads/MakingMostofPLCM cTigh\%20(1).pdf.

[10] Murphy, J. (2005). Connecting Teacher Leadership and School Improvement . California: Corwin Press.

[11] Norman D. Aitken, M. D. (2014). Academic Leaders and Faculty Developers: Creating an Institutional Culture that Values Teaching, To Improve the Academy. Retrieved from https://digitalcommons.unl.edu/cgi/viewcontent.cgi?artic le $=1299$ \& context $=$ podimproveacad.

[12] Owen, S. (2014, July). Teacher professional learning communities: Going beyond contrived collegiality toward challenging debate and collegial learning and professional growth. Australian Journal of Adult Learning, 54.

[13] Paulsen, K. A. (2002). Faculty Motivation: The Role of a Supportive Teaching Culture. In P. S. Associates, How Administrators Can Improve Teaching: Moving from Talk to Action in Higher Education (pp. 69-78). San Francisco: Josey - Bass. Retrieved from https://onlinelibrary.wiley.com/doi/pdf/10.1002/tl.7807.

[14] Peng, W.-J. M. (2014, 01). Emerging perceptions of teacher quality and teacher development in China. International Journal of Educational Development, 34, p. 77-89.

[15] Rebecca DuFour, R. E. (2004). Whatever It Takes: How Professional Learning Communities Respond When Kids Don't Learn . Solution Tree Press.

[16] Richard DuFour, R. J. (2009). High-Lverage Strategies for Principal LeadershIP. Educational Leadership, 6268.

[17] Thompson, S. C. (2004). Professional Learning Communities, leadership and student learning. Retrieved from Research Middle Level Education Online:

http://www.nmsa.org/Publications/RMLEOnline/tabid/1 01/Default.aspx
[18] Tiberius, R. S. (1993). Alliances for Change: A Procedure for Improving Teaching Through Conversations with Learners and Partnerships with Colleagues. Journal of Staff, Program and Organization Department, 11-23.

[19] Tim Hardy, V. K. (2007). Towards creating effective learning environments for science teachers: the role of a science educator in the tertiary setting. Retrieved from https://www.tandfonline.com/doi/abs/10.1080/09500699 40160210.

[20] W. Alan Wright, M. C. (1994). Teaching Improvement Practices: New Perspectives. Retrieved from https://digitalcommons.unl.edu/cgi/viewcontent.cgi?artic le $=1326 \&$ context $=$ podimproveacad .

[21] Walker, R. C. (1993). Revitalizing faculty work through intrinsic rewards. In R. D. Adam, Recognizing Faculty Work: Reward Systems for the Year 2000 (pp. 87-95). San Francisco: Jossey- Bass.

[22] Weimer, M. (2013). Defining Teaching Effectiveness. https://www.facultyfocus.com/articles/teachingprofessor-blog/defining-teaching-effectiveness/.

[23] Yvonne L. Goddard, R. D.-M. (2011). A Theoretical and Empirical Investigation of Teacher Collaboration for School Improvement and Student Achievement in Public Elementary Schools. Retrieved from https://education.illinoisstate.edu/downloads/casei/collab oration_studentachievement.pdf.

[24] Co N.T and Mai N.T. (2014). Văn hóa trong giảng dạy ngoai ngũ. Extracted from http://repository.ulis.vnu.edu.vn/bitstream/ULIS_123456 789/748/1/Nguy\%E1\%BB\%85n\%20Th\%E1\%BB\%8B $\% 20 \mathrm{C} \% \mathrm{C} 6 \% \mathrm{~A} 1 \% 2 \mathrm{~B} \% 20 \mathrm{Nguy} \% \mathrm{E} 1 \% \mathrm{BB} \% 85 \mathrm{n} \% 20 \mathrm{Mai}$. pdf. 


\title{
Xây dựng văn hóa hỗ trợ giảng dạy nhằm gia tăng hiệu quả giảng dạy
}

\author{
Lê Bích Thủy \\ Trường Đại học Kinh tế - Luật, ĐHQG HCM \\ Tác giả liên hệ: thuylb@uel.edu.vn \\ Ngày nhận bản thảo: 22-6-2018, ngày chấp nhận đăng: 24-8-2018, ngày đăng 29-10-2018
}

Tóm tắt-Bài viết này nghiên cứu sự tồn tại của văn hóa hỗ trọ̣ giảng dạy tại một trường đại học công lập ở Việt Nam nhằm thúc đẩy việc dạy tốt, dựa trên ba câu hỏi nghiên cứu với mục đích tìm hiểu (2) Thực trạng của các hoạt động hỗ trợ giảng dạy tại học đường và (2) hiệu quả của những hoạt động này từ quan điểm của giảng viên và (3) nhu cầu về những hoạt động tương tự phục vụ cho việc dạy tốt. Nghiên cứu được thực hiện dưới dạng khảo sát với dữ liệu được thu thập bằng bảng câu hỏi trực tuyến. Từ việc phân tích dữ liệu và các kết quả nghiên cứu, bài viết đề xuất một số phương pháp để tăng cường hay thiết lập văn hóa hỗ trọ̣ giảng dạy tại các trường đại học khác.

Tù khóa-Văn hóa học đường, dạy tốt, hiệu quả giảng dạy, văn hóa giảng dạy, phản hồi... 